\title{
Pengaruh Pendidikan Kesehatan tentang Kehamilan Risiko Tinggi melalui Layanan Pesan Singkat terhadap Peningkatan Pengetahuan dan Sikap Ibu Hamil
}

\author{
Esti Hitatami, ${ }^{1}$ BonyWiem Lestari, ${ }^{2}$ Herman Susanto, ${ }^{3}$ Dany Hilmanto ${ }^{4}$ Tina Dewi Judistiani, ${ }^{2,5}$ Deni K Sunjaya ${ }^{6}$ \\ Firman F. Wirakusuma ${ }^{7}$ \\ ${ }^{1}$ Mahasiswa Program Studi Magister Kebidanan Fakultas Kedokteran Universitas Padjadjaran, \\ ${ }^{2}$ Departemen Epidemiologi dan BiostatistikaUniversitas Padjadjaran, \\ ${ }^{3}$ Departemen Obstetri dan Ginekologi Fakultas Kedokteran Universitas Padjadjaran/Rumah Sakit dr. Hasan Sadikin, \\ ${ }^{4}$ Departemen Ilmu Kesehatan Anak Fakultas Kedokteran Universitas Padjadjaran/ Rumah Sakit dr. Hasan Sadikin, \\ ${ }^{5}$ Program Studi Diploma Kebidanan Universitas Padjadjaran, \\ ${ }^{6}$ Departemen Ilmu Kesehatan Masyarakat Universitas Padjadjaran
}

\begin{abstract}
Abstrak
Angka Kematian Ibu (AKI) di Indonesia masih cukup tinggi, dibandingkan dengan negara ASEAN lainnya. Kematian ibu yang tinggi tersebut disebabkan oleh komplikasi saat kehamilan dan persalinan. World Health Organization (WHO) memperkirakan bahwa 15-20\% ibu hamil baik di negara maju maupun berkembang akan mengalami risiko tinggi (risti) dan/atau komplikasi kehamilan. Salah satu penyebab terjadinya kehamilan risiko tinggi pada ibu hamil adalah kurangnya pengetahuan dan sikap positif ibu tentang kesehatan reproduksi. Hal ini dapat disebabkan oleh rendahnya status sosial ekonomi, pendidikan yang rendah, kesenjangan keterpaparan informasi, faktor kepercayaan dan pengalaman. Untuk mengoptimalkan pengetahuan dan sikap ini perlu dilakukan pendidikan kesehatan melalui pemberian layanan pesan singkat lewat telepon seluler. Oleh karena itu penelitian ini bertujuan untuk mengukur pengaruh pendidikan kesehatan tentang kehamilan risiko tinggi melalui layanan pesan singkat terhadap peningkatan pengetahuan dan sikap ibu hamil. Penelitian ini merupakan penelitian quasi experimental dengan rancangan pre test-post test control group design dengan jumlah sampel 114 orang ibu hamil. Pengambilan sampel ibu hamil dilakukan dengan cara randomisasi blok permutasi sehingga diperoleh 57 orang ibu hamil untuk kelompok intervensi dan 57 orang ibu hamil untuk kelompok kontrol. Variabel pengetahuan dan sikap tentang kehamilan risiko tinggi diukur dengan menggunakan kuesioner sebelum dan sesudah diberikan pendidikan kesehatan berupa layanan pesan singkat. Perbedaan peningkatan pengetahuan dan sikap pada pada kelompok intervensi dan kontrol diuji secara statistik dengan uji $t$ tidak berpasangan.Penelitian dilaksanakan dari bulan Desember 2013 sampai dengan bulan Januari 2014. Hasil penelitian pada kelompok intervensi menunjukkan adanya peningkatan skor rata-rata pengetahuan dari 49,2 $\pm 11,6$ menjadi $60,6 \pm 12,6(\mathrm{p}<0,05)$. Selain itu terdapat peningkatan skor ratarata sikap dari $71,4 \pm 9,3$ menjadi 76,3 $\pm 5,7 \quad(\mathrm{p}<0,05)$. Sedangkan uji beda selisih peningkatan pengetahuan dan sikap antar kelompok intervensi dan kontrol menunjukkan perbedaan selisih pengetahuan bermakna dengan skor 11,4 $\pm 12,5$ dan 1,4 $\pm 16,9$ ( $<<0,05)$. Untuk variabel sikap, terdapat perbedaan selisih skor sikap yang bermakna pada kelompok intervensi sebesar 4,9 $\pm 14,7$ dan kelompok kontrol sebesar $-5,9 \pm 9,6(\mathrm{p}<0,05)$. Berdasarkan hasil penelitian dapat disimpulkan bahwa pendidikan kesehatan dengan layanan pesan singkat dapat meningkatkan pengetahuan dan sikap ibu hamil tentang kehamilan risiko tinggi.
\end{abstract}

Kata kunci : Kehamilan risiko tinggi, layanan pesan singkat, ibu hamil 


\title{
The Impact of Health Education Through Short Message Service Towards Knowledge and Attitude on Highrisk Pregnancy among Pregnant Women in Bandung Municipality
}

\begin{abstract}
The maternal mortality rate in Indonesia is still consider ably high compared to other ASEAN countries. Complications during pregnancy and delivery contribute highly to that number. The World Health Organization (WHO) estimates that 15 - 20\% pregnant women, either in advanced or developing countries, are subject to high risks pregnancy. One of the causes of the risks in pregnancy is the lack of knowledge and positive attitude among pregnant women towards reproductive health, which is the result of low social-economicstatus,low educational level, lack of informationexposure, incorrectreliance, and lack of experience. To optimize theknowledge and attitude, a health education supplemented through the short message service in cellular phones needs to be done.Health education through short message service has many advantages such as easy, fast, cheap, and provide broad range of service area. Thus, we aimed to measure the impact of health education towards knowledge and attitude of pregnant women related to high risk pregnancy, after the administration of the health education through cellular short messages. This research was a quasi experimental study using pretest-post-test control group design.Based on eligibility criteria, we recruited 114 pregnant women. The procurement of subjects was done by permutation block randomization with the result of 57 subjects eachin both intervention and non-intervention groups. The variables of knowledge and attitude about high risk pregnancy were measured before and after intervention. The intervention which is the administration of cellular short messages was given once a day during 45 days.The increased knowledge and attitude between intervention and control groups was then compared using independent t-test. This research was conducted in the span of December 2013 to January 2014. The results of the study showed that in the intervention group, there was a knowledge score increase from the average pre-test score of 49,2 $\pm 11,6$ to post-test $60,6 \pm$ SD 12,6(p-value $<0.05$ ). There was also an

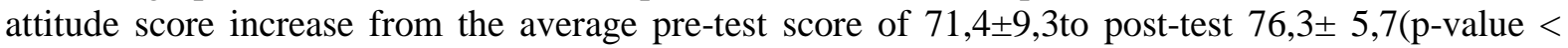
0.05). Mean while, there is a difference of test scores for knowledge and attitude between the intervention and non-intervention groups. For knowledge, there is an increase score of $11.4 \pm 12.5$ in intervention group where as in non-intervention group it was only $1.4 \pm 16.9$ ( $p$-value $<0.05$ ). Regardingattitude, there is an increases core of 4.9 \pm 9.6 in intervention group, mean while in nonintervention group it was only $-5.9 \pm 14.7$ (p-value $<0.05$ ). Our results showed that health education using short messages service canimprove the knowledge and attitude of pregnant women related to high-risk pregnancy.
\end{abstract}

Keywords: High-risk pregnancy, short message service, pregnant women 


\section{Pendahuluan}

Jawa Barat tercatat sebagai penyumbang tertinggi Angka Kematian Ibu di Indonesia. Pada tahun 2012 sebanyak 228 orang ibu hamil meninggal di kabupaten Bandung termasuk kategori tertinggi yaitu sebesar 45 orang ibu hamil meninggal setelah kabupaten Cirebon, Indramayu, dan Karawang. Di Jawa Barat tercatat kematian neonatal sebanyak 276 kasus dengan penyebab terbanyak BBLR 92 kasus dan lahir mati 129 kasus. ${ }^{1}$ Pada tahun 2012 dari 68.338 ibu hamil di kabupaten Bandung terdapat $9.496(69,9 \%)$ ibu hamil dengan risiko tinggi dalam kehamilannya, sementara komplikasi yang tertangani baru 18,9\%. Berdasarkan data Dinas Kesehatan kabupaten Bandung, puskesmas yang tertinggi jumlah ibu hamil yang terdeteksi risiko tinggi adalah Puskesmas Katapang sebesar 44,6\% diikuti puskesmas Jelekong yaitu 44,2\%. ${ }^{2}$

Penyebab kematian ibu bersalin yang tinggi di kabupaten Bandung terutama disebabkan oleh kasus perdarahan, diikuti oleh eklamsi atau preeklamsi, sedangkan kematian bayi yang terbanyak disebabkan oleh BBLR. Tingginya angka kematian ibu dan bayi tersebut menunjukkan permasalahan pada ibu hamil yang disebabkan oleh rendahnya kualitas pengetahuan, sikap, perilaku dan lingkungan kesehatan masyarakat, selain rendahnya pendidikan ibu hamil dan kurangnya pengetahuan ibu hamil tentang kehamilan risiko tinggi. ${ }^{3}$ Salah satu upaya dengan memberikan informasi tentang kehamilan risiko tinggi dilakukan melalui pendidikan kesehatan yang dirancang dengan tepat sehingga klien mudah memahami dan mengingat informasi sertaberpedoman pada pemilihan topik, metode, strategi, maupun mediayang memadai dalam upaya peningkatan pengetahuan dan pembentukan sikap yang positif. ${ }^{4}$ Dewasa ini perkembangan sistem informasi menyebabkan terjadinya perubahan yang cukup signifikan dalam segala bidang. Meningkatnya penggunaan teknologi informasi dan komunikasi, khususnya internet, dan seluler telah membawa setiap orang dapat melaksanakan berbagai aktivitas dengan lebih cepat, tepat dan berkualitas. Telepon seluler dan internet sudah tidak asing lagi bagi masyarakat Indonesia karena harga yang relatif terjangkau serta tersedianya berbagai fitur layanan yang mampu memberikan kemudahan dalam berkomunikasi sehingga alat ini makin banyak diminati masyarakat. Sebagian besar masyarakat Indonesia memanfaatkan teknologi seluler sebatas fasilitas komunikasi dan layanan pesan singkat untuk kepentingan umum. Semakin banyaknya pengguna seluler dengan fasilitas layanan pesan singkatnya ini berpeluang besar untuk dapat dimanfaatkan sebagai media dalam kegiatan pendidikan kesehatan bagi masyarakat. $^{5,6,7}$

Intervensi dilakukan terhadap perubahan pengetahuan dan sikap penting dilakukan karena faktor pengetahuan dan sikap tersebut merupakan faktor yang paling mempengaruhi kesehatan seseorang. ${ }^{8}$ Upaya peningkatan pengetahuan dan sikap ibu hamil dapat dilakukan lewat intervensi pendidikan kesehatan melalui pemanfaatan media telepon seluler dengan fitur layanan pesan singkat. Layanan keunggulan pesan singkat ini memiliki keunggulan karena mampu menyebarluaskan pesan dengan mudah, cepat, murah dan jangkauan yang luas. ${ }^{9}$ Berdasarkan uraian diatas tujuan penelitian ini adalah mengukur pengaruh pemberian pendidikan kesehatan tentang kehamilan risiko tinggi dengan layanan pesan singkat terhadap peningkatan pengetahuan dan sikap ibu hamil.

\section{Metode}

Penelitian ini merupakan penelitian quasi experimental dengan rancangan pre test-post test control group design dengan jumlah sampel 114 orang ibu hamil. Kriteria inklusipada pada penelitian ini adalah ibu hamil trimester 1-3, bisa membaca menulis, memiliki telepon seluler pribadi, bertempat tinggal di wilayah kerja puskesmas Katapang Kabupaten Bandung. Subjek penelitian ini kemudian dialokasikan ke dalam kelompok intervensi dan kelompok kontrol dengan randomisasi blok permutasi sehingga masing-masing kelompok berjumlah 57 orang. Variabel pengetahuan dan sikap diukur dengan menggunakan kuesioner sebelum dan sesudah diberikan pendidikan kesehatan berupa layanan pesan singkat. Selanjutnya, kelompok intervensi diberi materi layanan pesan singkat tentang kehamilan risiko tinggi, sedangkan dan kelompok kontrol diberi materi layanan pesan singkat tentang kesehatan umum, yang diberikan setiap hari selama 45 hari. Pengambilan sampel ibu hamil dilakukan dengan cara randomisasi blok permutasi untuk mendapatkan jumlah 
Esti Hitatami. : Pengaruh Pendidikan Kesehatan tentang Kehamilan Risiko Tinggi melalui Layanan Pesan Singkat terhadap Peningkatan Pengetahuan dan Sikap Ibu Hamil

subjek yang sama dalam kedua kelompok penelitian sehingga diperoleh jumlah sampel kedua kelompok baik kelompok intervensi maupun kelompok non intervensi dengan 57 orang. Perbedaan peningkatan pengetahuan dan sikap sebelum dan sesudah diberi layanan pesan singkat dengan uji $t$ berpasangan.Perbedaan selisih pengetahuan dan sikap pada kelompok intervensi dan kelompok kontrol dilakukan analisis dengan uji t tidak berpasangan. Bila data berdistribusi normal, dilakukan uji statistik parametrik, sebaliknya bila data tidak berdistribusi normal dilakukan uji statistik nonparametrik. Penelitian dilaksanakan dari bulan Desember 2013 sampai dengan bulan Januari 2014.

\section{Hasil}

Tabel 1. Karakteristik Subjek Penelitian

\begin{tabular}{|c|c|c|c|c|c|}
\hline \multirow{2}{*}{$\begin{array}{l}\text { Karakteristik } \\
\text { Responden }\end{array}$} & \multicolumn{2}{|c|}{ Intervensi } & \multicolumn{2}{|c|}{ Non-intervensi } & \multirow{2}{*}{ Nilai $p$} \\
\hline & $\mathrm{n}=57$ & $\%$ & $\mathrm{n}=57$ & $\%$ & \\
\hline \multicolumn{6}{|l|}{ Usia } \\
\hline 20 tahun & 6 & 40 & 9 & 60 & \multirow{3}{*}{0,705} \\
\hline $20-35$ tahun & 40 & 51,3 & 38 & 48,7 & \\
\hline 35 tahun & 11 & 52,4 & 10 & 47,6 & \\
\hline \multicolumn{6}{|l|}{ PendidikanTerakhir } \\
\hline Tamat SD/sederajat & 16 & 55,2 & 13 & 44,8 & \multirow{5}{*}{0,494} \\
\hline Tamat SLTP/sederajat & 24 & 53,3 & 21 & 46,7 & \\
\hline Tamat SLTA/ sederajat & 13 & 38,2 & 21 & 61,8 & \\
\hline Tamat Diploma & 3 & 75,0 & 1 & 25,0 & \\
\hline TamatPerguruantinggi & 1 & 50,0 & 1 & 50,0 & \\
\hline \multicolumn{6}{|l|}{ Paritas } \\
\hline Nuli para & 14 & 41,2 & 20 & 58,8 & \multirow{3}{*}{0,451} \\
\hline Multipara & 40 & 53,3 & 35 & 46,7 & \\
\hline Grande Multipara & 3 & 60,0 & 2 & 40,0 & \\
\hline \multicolumn{6}{|l|}{ Pekerjaan } \\
\hline Bekerja & 9 & 37,5 & 15 & 62,5 & \multirow[t]{2}{*}{0,168} \\
\hline Tidakbekerja & 48 & 53,3 & 42 & 46,7 & \\
\hline
\end{tabular}

Keterangan : Nilai p dihitung berdasarkan uji Chi Square

Berdasarkan tabel 1 diatas, hasil uji statistik karakteristik responden baik pada usia, pendidikan, paritas dan pekerjaan semua menunjukkan perbedaan yang tidak signifikan $(\mathrm{p}>0,05)$ antara kedua kelompok perlakuan (intervensi dan kontrol). Hal ini menunjukkan bahwa karakteristik kedua kelompok penelitian relatif setara sehingga hal ini memenuhi salah satu persyaratan dalam penelitian eksperimen. 
Esti Hitatami. : Pengaruh Pendidikan Kesehatan tentang Kehamilan Risiko Tinggi melalui Layanan Pesan Singkat terhadap Peningkatan Pengetahuan dan Sikap Ibu Hamil

Tabel 2 Perbedaan peningkatan pengetahuan dan sikap tentang kehamilan risiko tinggi sebelum (pre) dan sesudah (post) diberi pendidikan kesehatan melalui layanan pesan singkat

\begin{tabular}{|c|c|c|c|c|c|c|c|c|}
\hline \multirow[t]{2}{*}{ Variabel } & \multicolumn{2}{|c|}{$\begin{array}{c}\text { Intervensi } \\
(\mathrm{n}=57)\end{array}$} & \multirow{2}{*}{$\begin{array}{l}\text { t- } \\
\text { hitung/ } \\
\left(Z_{w}\right) \\
\end{array}$} & \multirow{2}{*}{$\begin{array}{c}\text { Nilai } \\
\mathbf{p}\end{array}$} & \multicolumn{2}{|c|}{$\begin{array}{c}\text { Non-intervensi } \\
(\mathrm{n}=57)\end{array}$} & \multirow{2}{*}{$\begin{array}{l}\mathbf{t}- \\
\text { hitung/ } \\
\left(Z_{w}\right) \\
\end{array}$} & \multirow[t]{2}{*}{ Nilai p } \\
\hline & Pre & Post & & & Pre & Post & & \\
\hline \multicolumn{9}{|l|}{ Pengetahuan } \\
\hline $\operatorname{Mean}(\mathrm{SD})$ & $49,2(11,6)$ & $60,6(12,6)$ & - & & $46,3(12,5)$ & $47,8(13,5)$ & - & \\
\hline Median & 50 & 60 & 6,910 & 0,000 & 46,7 & 46,7 & 0,655 & 0,515 \\
\hline Rentang & $23,3-70$ & $33,3-86,7$ & & & $10-63,3$ & $20-83,3$ & & \\
\hline \multicolumn{9}{|l|}{ Sikap } \\
\hline Mean (SD) & $71,4(9,3)$ & $76,3(5,7)$ & & & $69,3(13,1)$ & $63,4(7,3)$ & & \\
\hline Median & 72,7 & 75,3 & & & 68,7 & 65,3 & & \\
\hline Rentang & $56,7-95,3$ & $70-90$ & $\begin{array}{c}- \\
3,881\end{array}$ & 0,000 & $20-96,7$ & $20-70$ & $\begin{array}{l}- \\
3,105\end{array}$ & 0,002 \\
\hline
\end{tabular}

Ket : Pengetahuan dengan $\mathrm{t}_{\text {-hitung }}$ dan uji $\mathrm{t}$ berpasangan

Sikap dengan $\mathrm{Zw}$ dan uji wilcoxon

Berdasarkan tabel 2 diatas, terdapat peningkatan pengetahuan pada kelompok intervensi dengan perbedaan bermakna $(\mathrm{p}<0,05)$ sedangkan pada kelompok non-intervensi tidak bermakna $(\mathrm{p}=0,515)$. Pada sikap, terdapat peningkatan sikap pada kelompok intervensi dengan perbedaan bermakna $(\mathrm{p}<0,05)$ begitu juga pada kelompok non intervensi $(\mathrm{p}=0,002)$.

Tabel 3. Pengaruh pendidikan kesehatan dengan layanan pesan singkat terhadap peningkatan pengetahuan dan sikap ibu hamil tentang kehamilan risiko tinggi

\begin{tabular}{|c|c|c|c|}
\hline \multirow{3}{*}{ Variabel } & \multicolumn{2}{|l|}{ Kelompok } & \multirow{3}{*}{ Nilai p } \\
\hline & Intervensi & Non-Intervensi & \\
\hline & $\mathrm{n}: 57$ & $\mathrm{n}: 57$ & \\
\hline \multicolumn{4}{|l|}{ Pengetahuan } \\
\hline \multicolumn{4}{|l|}{ Pretes } \\
\hline Mean & $49,2(11,6)$ & $46,4(12,5)$ & $0,207 *$ \\
\hline Rentang & $23,3-70,0$ & $10,0-63,3$ & \\
\hline \multicolumn{4}{|l|}{ Posttest } \\
\hline Mean & $60,6(12,6)$ & $47,8(13,5)$ & $0,000 *$ \\
\hline Rentang & $33,3-86,7$ & $20-83,3$ & \\
\hline Selisih pengetahuan & 11,4 & 1,4 & $0,001 * *$ \\
\hline \multicolumn{4}{|l|}{ Sikap } \\
\hline \multicolumn{4}{|l|}{ Pretes } \\
\hline Mean & $71,4(9,3)$ & $69,3(13,1)$ & \\
\hline Rentang & $56,7-95,3$ & $20,0-96,7$ & $0,324 * *$ \\
\hline \multicolumn{4}{|l|}{ Posttest } \\
\hline Mean & $76,3(5,7)$ & $63,4(7,3)$ & \\
\hline Rentang & $70-90$ & $20-70$ & $0,000^{*}$ \\
\hline Selisih sikap & 4,9 & $-5,9$ & $0,000^{* *}$ \\
\hline
\end{tabular}

Ket : Pengetahuan *) dan **) Uji t tidak berpasangan

Sikap *) Uji Mann Whitney dan **) Uji t tidak berpasangan

Berdasarkan tabel 3 diatas tidak terdapat perbedaan pengetahuan sebelum perlakuan pada kedua kelompok (kelompok intervensi dan nonintervensi) dengan nilai $\mathrm{p}=0,207$ artinya kedua kelompok homogen yaitu pengetahuan awal relatif sama. Selanjutnya, setelah diberi perlakuan antara kelompok intervensi dan nonintervensi didapatkan perbedaan peningkatan pengetahuan yang bermakna $(p<0,01$. Hal ini menunjukkan bahwa pemberian layanan pesan 
singkat dapat meningkatkan pengetahuan ibu hamil tentang kehamilan risiko tinggi.

Selanjutnya, terdapat selisih rata-rata pengetahuan pada kelompok intervensi dan nonintervensi yang bermakna $(\mathrm{p}<0,01)$. Tabel 3 diatas juga menunjukkan bahwa uji perbedaan sikap sebelum perlakuan pada kedua kelompok (kelompok intervensi dan non-intervensi) ditemukan perbedaan yang tidak bermakna $(\mathrm{p}=$ $0,324)$ artinya kedua kelompok homogen yaitu sikap awal relatif sama. Selanjutnya, setelah diberi perlakuan antara kelompok intervensi dan non-intervensi didapatkan perbedaan sikap yang bermakna $(p<0,01)$. Hal ini menunjukkan bahwa pemberian layanan pesan singkat dapat meningkatkan sikap ibu hamil tentang kehamilan risiko tinggi. Analisis lebih lanjut terhadap selisih rata-rata sikap pada kelompok intervensi dan non-intervensi didapatkan perbedaan yang bermakna dengan nilai $(\mathrm{p}=0,00)$.

\section{Pembahasan}

Berdasarkan hasil penelitian diatas, pada kelompok intervensi setelah diberikan perlakuan berupa pendidikan kesehatan melalui layanan pesan singkat terlihat adanya peningkatan skor pengetahuan dan sikap dengan hasil yang bermakna.

Untuk meningkatkan pengetahuan dan sikap perlu dilakukan pendidikan kesehatan.

Pendidikan kesehatan pada hakekatnya merupakan suatu kegiatan atau usaha untuk menyampaikan pesan kesehatan kepada masyarakat, kelompok, atau individu, dengan harapan dengan pesan tersebut masyarakat, kelompok, atau individu dapat memperoleh pengetahuan tentang kesehatan. Akhirnya pengetahuan tersebut dapat membawa akibat terhadap perubahan perilaku sasaran. ${ }^{9}$ Sikap dan perilaku yang didasari oleh pengetahuan akan lebih bertahan lama dari pada yang tidak didasari pengetahuan. ${ }^{10}$ Kemampuan seseorang untuk mengingat informasi dari membaca akan jauh lebih menetap dibandingkan dengan hanya mendengar. ${ }^{11}$ Melalui intervensi dan pengembangan media pendidikan kesehatan yang sesuai, diharapkan dapat memberikan hasil belajar yang maksimal. ${ }^{12}$ Pendidikan kesehatan sebagai bagian dari promosi kesehatan diharapkan dapat membentuk kesadaran di dalam diri orang-orang tentang pentingnya kesehatan bagi mereka sehingga mereka sendirilah yang akan melakukan usaha- usaha untuk menyehatkan diri mereka. ${ }^{13}$

Dewasa ini bidang promosi kesehatan telah menjadi hal yang penting dimana telah terjadi perkembangan yang signifikan dalam hal perhatian dunia mengenai masalah promosi/ pendidikan kesehatan. World Health Organization (WHO), menyelenggarakan Konferensi Internasional pertama bidang promosi yang diadakan di Ottawa, Kanada pada 21 November 1986. Konferensi ini dihadiri oleh para ahli kesehatan seluruh dunia, dan menghasilkan sebuah dokumen penting yang disebut Ottawa Charter (Piagam Ottawa). Piagam ini menjadi rujukan bagi program promosi di tiap negara, termasuk Indonesia. ${ }^{13,14}$ Konferensi Ottawa menghimbau organisasi kesehatan dunia untuk mendukung promosi/ pendidikan kesehatan di setiap negara dalam mengembangkan strategi dan program promosi/ pendidikan kesehatan. ${ }^{14}$ Strategi promosi kesehatan adalah cara atau langkah yang diperlukan untuk mencapai, memperlancar atau mempercepat pencapaian tujuan promosi kesehatan. Dalam strategi promosi kesehatan berdasarkan piagam Ottawa, ada berbagai macam upaya pemasaran produk dan jasa yang telah dilakukan salah satunya yaitu melalui media. ${ }^{14}$

Merujuk ke piagam Ottawa diatas penelitian tentang pemberian pendidikan kesehatan melalui media telepon seluler dengan memanfaatkan fitur layanan pesan singkat mampu menghasilkan peningkatan pengetahuan dan sikap sehingga strategi ini bisa dikembangkan dalam upaya mempercepat tujuan promosi kesehatan. ${ }^{15}$

Penelitian dibawah ini tentang pendidikan kesehatan di bidang kesehatan reproduksi juga mendukung penelitian diatas dengan judul "Pemanfaatan Layanan Pesan Singkat sebagai Media Promosi Kesehatan dalam Upaya Peningkatan Pengetahuan dan Perubahan Sikap Remaja mengenai Aborsi". Penelitian ini menggunakan metode quasi experimental dengan rancangan randomized pretest-posttest with control group. Hasil penelitian menyebutkan ada perbedaan bermakna pada pengetahuan responden setelah diberi intervensi layanan pesan singkat dengan nilai $(\mathrm{p}<0,05)$, begitu juga ada perbedaan bermakna pada sikap responden setelah diberi intervensi layanan pesan singkat dengan nilai $(p<0,01)$. Hal ini menunjukkan bahwa melalui pemanfaatan telepon seluler dengan fitur layanan pesan singkat dalam promosi kesehatan tentang aborsi mampu 
meningkatkan secara signifikan pengetahuan dan sikap respondennnya. ${ }^{16}$ Selain itu terdapat peningkatan nilai rata-rata hasil pretestposttest dengan selisih 38,9\% untuk pengetahuan dan 6,6\% untuk sikap pada kelompok intervensi artinya pemanfaatan layanan pesan singkat sebagai media promosi kesehatan mampu secara efektif meningkatkan pengetahuan dan mempengaruhi sikap positif (tidak mendukung) siswa/i terkait masalah aborsi. ${ }^{16}$

Penelitian yang mendukung lainnya adalah "Keefektifan Pengingat Pesan dengan Layanan Pesan Singkat sebagai Media Promosi Kesehatan Ibu Hamil di Daerah Terpencil". Hasil penelitian menunjukkan bahwa terdapat perbedaan signifikan antara perlakuan sebelum dan setelah diberikan intervensi menggunakan layanan pesan singkat berkaitan dengan pemahaman asupan gizi dengan nilai $(\mathrm{p}<0,05)$. Hal ini menunjukkan bahwa layanan pesan singkat pengingat ini dapat meningkatkan pengetahuan ibu hamil mengenai komplikasi. Selain itu bahwa program intervensi yang dilakukan efektif dalam meningkatkan pengetahuan ibu hamil mengenai asupan gizi selama kehamilan. Penelitian lainnya berjudul "Behavior Change Interventions Delivered by Mobile Telephone Short-Message Service" menunjukkan bahwa intervensi layanan pesan singkat yang disampaikan secara signifikan mampu merubah perilaku positif yaitu berhenti merokok dan meningkatkan kepatuhan dalam pemeliharaan kesehatan. ${ }^{18}$

Penelitian di Argentina pemanfaatan media layanan pesan singkat kepada ibu-ibu hamil memperlihatkan bahwa teknologi merupakan solusi sehingga dapat meningkatkan pengetahuan tentang kehamilan, persalinan dan nifas. ${ }^{7}$ Teknologi telepon seluler ini dapat digunakan dalam rangka mengembangkan strategi meningkatkan pelayanan kesehatan ibu terutama di negara berkembang, di mana akses kesehatan yang terbatas berakibat pada perawatan antenatal yang rendah dan angka kematian ibu dan perinatal yang tinggi. Hasil penelitian menunjukkan bahwa layanan pesan singkat menyebabkan meningkatnya kehadiran ibu hamil di pelayanan kesehatan serta efektif dalam meningkatkan upaya promotif guna perubahan pengetahuan, sikap dan perilaku kesehatan. Layanan pesan singkat memiliki potensi untuk mempengaruhi perubahan perilaku karena efisiensi, biaya rendah, dan kemampuan untuk menyebarluaskan informasi kesehatan, bahkan dapat mencapai populasi yang sulit dijangkau. Telepon seluler ini dapat menjadi pilihan yang sangat berguna untuk meningkatkan perawatan antenatal. ${ }^{7}$ Salah satu penelitian lain di Nigeria menyediakan fasilitas layanan pesan singkat gratis menyebarkan pesan masal mengenai pencegahan HIV. Hasil membuktikan bahwa dengan menggunakan layanan pesan singkat terbukti signifikan dalam memberikan efek positif terhadap perubahan kognitif, sikap bahkan perilaku masyarakat, dimana responden mau melakukan tes infeksi menular seksual dan menggunakan kondom secara konsisten. ${ }^{19}$

Dalam penelaahan berbagai jurnal didapatkan bahwa pendidikan kesehatan yang diberikan dengan layanan pesan singkat dapat mempengaruhi perilaku sasaran sehingga dapat meningkatkan pengetahuan, sikap serta perubahan perilaku. ${ }^{6}$ Simpulan semakin meningkatnya pengguna seluler berpeluang untuk memanfaatkan teknologi seluler sebagai media dalam kegiatan pendidikan kesehatan menjadi semakin besar. Fasilitas layanan pesan singkat inilah yang bisa dimanfaatkan untuk media pendidikan kesehatan bagi masyarakat. Disamping biaya yang relative murah, mudah dan cepat dalam penyebaran informasi. Peluang inilah yang dapat dimanfaatkan oleh pengambil kebijakan di dalam pemerintahan dalam meningkatkan kegiatan pendidikan kesehatan sehingga dapat membantu meningkatkan pengetahuan masyarakat. ${ }^{16}$ Penelitian kami menunjukkan bahwa pemanfaatan telepon seluler berupa layanan pesan singkat ini berpengaruh secara bermakna dalam meningkatkan pengetahuan dan sikap ibu hamil tentang kehamilan risiko tinggi.

\section{Simpulan}

Dari hasil penelitian dapat disimpulkan bahwa pendidikan kesehatan dengan layanan pesan singkat dapat meningkatkan pengetahuan dan sikap ibu hamil tentang kehamilan risiko tinggi.

\section{Daftar Pustaka}

1. Dinas Kesehatan Kabupaten Bandung. Laporan Tahunan Dinas Kesehatan Kabupaten Bandung 2012. (Diunduh tgl 17 September 2013). Diambil dari

:http://www.bandungkab.go.id/uploads/LAPTAH _KAB_BANDUNG_20121.pdf. 
Esti Hitatami. : Pengaruh Pendidikan Kesehatan tentang Kehamilan Risiko Tinggi melalui Layanan Pesan Singkat terhadap Peningkatan Pengetahuan dan Sikap Ibu Hamil

2. Dinas Kesehatan Kabupaten Bandung. Data Rekapitulasi PWS-KIA; 2013.

3. Dinas Propinsi Jawa Barat. Perubahan Rencana Pembangunan Jangka Menengah Daerah Propinsi Jawa Barat 2008-2013; 2008.

4. Rakhmadian K. Knowledge and Attitude about Woman in Childbearing Age at Primary Health Care of Muara Fajar about High Risk Pregnancy to Before and After the Counseling. 2012.

5. Koesnadi. Peran Media Massa, Jakarta: Rajawali Press: 1998.

6. Muhammad R. Kesiapan Masyarakat Menuju Era Masyarakat Informasi. Jurnal Penelitian Komunikasi, Informatika dan Media Massa. Pekommas. 2012; 15 (1): 47-8.

7. Cormick GKN, Rodgers A, Buekens PM, Belizan JM, Althobe F. Interest of Pregnant Women In Use of SMS (Short Message Service) Text Messages For The Improvement of Prenatal and Post Natal Care. Productive Heatlh BMC Public Heatlh. 2012; 9 (9).

8. Emilia O. Promosi Kesehatan Dalam Lingkup Kesehatan Reproduksi. Yogyakarta: Pustaka Cendekia Press; 2008

9. Notoatmodjo S. Prinsip-Prinsip Dasar Ilmu Kesehatan Masyarakat. Jakarta: Rineka Cipta; 2005.

10. Notoatmodjo S. Pendidikan dan Perilaku Kesehatan. Jakarta: Rineka Cipta; 2003

11. Yashinta Ardhiani P. Peningkatan Pengetahuan dan Sikap Kesehatan Reproduksi Siswa SMP Melalui Leaflet dan SMS. Yogyakarta: Universitas Gadjah Mada; 2013.

12. Anya SE, Hydara A, Jaiteh LES. Antenatal care in The Gambia: Missedopportunity for information, education and communication. BMC Preg Childbirth. 2008 (diunduh 18 Oktober 2012);8(9).
13. World Health Organization, Milestonesin Health Promotion Statements from Global Conferences WHO Press, 20 Avenue Appia, 1211 Geneva 27, Switzerland, 2009

14. Sutomo B. Lima kebijakan Promosi Kesehatan. Dosen Poltekes, Semarang.2011. Diunduh dari : http://dentalsemarang.wordpress.com/2011/02/17 /isi-piagam-ottawa-charter/

15. Joo NS. Kim BT. Mobile Phone Short Message Service Messaging For Behaviour modification in a community Based weight Control Programme in Korea. Journal of Telemedicine and Telecare. $2007 ; 13: 416-20$.

16. Pribadi ET. Pemanfaatan SMS Pada Seluler Sebagai Media Promosi Kesehatan Dalam Upaya Peningkatan Pengetahuan dan Perubahan Sikap Remaja Mengenai Aborsi.Surabaya: Universitas Airlangga; 2009.

17. Herlina S. Sanjaya GK. Emilia O., Keefektifan SMS Reminder Sebagai Media Promosi Kesehatan Ibu Hamil di Daerah Terpencil. Seminar Nasional Informatika Medis 20132 - 4 Desember 2013:3

18. Briana S, Fjeldsoe BA, Alison L, Marshall, Yvette D, Miller. Behaviour Change Interventions Delieve By Mobile Telephone Short Message Service. American Journal of Preventive Medicine. 2009;36 (2):165-173.

19. Megan S. Lim C. Hellard ME, Aitken CK.. SMS STI: A Review of The Uses of Mobile Phone Text Messaging in Sexual Health. International Journal STD AIDS. 2008, 19: 287-90, 